\title{
Når arkeologi møter lokal kunnskap - etiske implikasjoner
}

\author{
ELIN Rose MyrvolL*
}

Title: When archaeology meets local knowledge - ethical impications.

Abstract: Archaeologists produce and communicate authorized stories concerning cultural heritage and the past. Their legitimacy is based on education, scientific methods and their connection with a research community. Their position as authorized producers of history is also emphasized by TV programmes presenting archaeologists as riddle-solving detectives. The main aim of this article is to focus on the dynamics between stories communicated by archaeologists and the stories passed on and communicated by members of a local community, and to discuss these. What happens when stories based on tradition and lore meet authorized stories? The latter sometimes overwrite or erase local lore and knowledge connected to features in the landscape. Some archaeological projects have, however, involved local participants and locally based knowledge. In addition, one should be aware that local and traditional knowledge are sometimes kept and transmitted within a family, local community or ethnic group. Local knowledge is therefore not always a resource that is accessible for archaeologists.

Key words: Traditional knowledge, local knowledge, ethics, communication, survey, landscape, archaeology.

Hvordan innvirker fagarkeologiske historier $p a ̊$ lokale historier om kulturminner og landskapene de inngår i? Hvordan er styrkeforholdet mellom fagarkeologisk viten og lokal viten? Hvilken rolle kan arkeologien spille i forhold til lokal stedsutvikling og verdiskaping? Hvilke etiske implikasjoner har dette?

I den tradisjonelle formidlingsarkeologien har kommunikasjonen mellom arkeologiske fagmiljøer og lokalbefolkning, generelt vært sentrert rundt arkeologenes kunnskap. Formålet har vært å formidle fagkunnskap til lokalbefolkningen. Arkeologenes utfordringer har i første rekke vært av pedagogiske karakter. Ett virkemiddel har vært å framheve det unike og særegne. Man har vektlagt tidsdybden i kulturmiljøene, fokusert på høvdinger og enkeltpersoner med høy sosial status, tidlig innovativ bruk av materialer og råstoffer, vidstrakte kontaktnett, sjeldne prestisjevarer etc. 
Kombinert med superlativer og adjektiver som eldst, tidligst, størst og vakrest har arkeologene skapt fengende og salgbare framstillinger av kulturhistorie og kulturminner (Karlsson og Gustafsson 2004).

De siste årene har imidlertid arkeologene i større grad blitt seg bevisst asymmetrien i formidlingssituasjonen. I stedet for enveis formidling har man lagt større vekt på dialog og interaksjon med målgruppene. I England og USA har denne innfallsvinkelen og involveringen av publikum i arkeologi og arkeologiske prosjekter fătt betegnelsen public archaeology (Jameson 2004; Merriman 2004). Utviklingen av dette feltet har også inspirert arkeologiske prosjekt i Norden (Svanberg Wahlgren 2007).

Jeg skal i det følgende se nærmere på arkeologenes faghistorier i møte med lokal kunnskap og lokalt produserte historier. Noen lokalsamfunn forvalter mange historier og kan vise til lang kontinuitet $\mathrm{i}$ bosettingshistorie. Andre er i større grad preget av utskifting og mobilitet og forvalter trolig færre stedsrelaterte historier om fortida. Jeg finner det derfor nødvendig å undersøke hvilke implikasjoner disse forskjellene innebærer for arkeologer som formidlere av faghistorier. Et annet moment er fredningsgrena for automatisk fredete kulturminner i Norge (lov om kulturminner av 1978 (kulturminneloven)). Samiske kulturminner eldre enn 100 år har status som automatisk freda, mens de øvrige kulturminnene må være eldre enn 1537 for å få en tilsvarende status. Har denne fredningsgrensa innvirkning på fangfolks holdning og interesse for lokal kunnskap om kulturminner, kulturmiljøer og landskap? Innledningsvis vil jeg skisseres hovedtendenser i formidlingen av arkeologi illustrert ved eksempler hovedsakelig fra NordNorge og Sverige
TILBAKEBLIKK - ARKEOLOGI OG FORMIDLING

Profesjonaliseringen av arkeologi som en egen disiplin, førte til at avstanden mellom faglig viten og lokal viten om kulturminner ble større. Diskursen i fagmiljøene har vært konsentrert rundt arkeologenes egne erfaringer og observasjoner av arkeologiske kulturminner og arkeologiske funn, samt skriftlig materiale i form av forskningsarbeider og historiske dokumenter. Lekfolks meningsproduksjon eller viten om arkeologiske kulturminner har fram til 1990-tallet, bare i liten grad sett som en relevant kilde for fagmiljøene. Kontakten har vært kjennetegnet av enveis formidling der arkeologer og arkeologiske fagmiljøer har forvaltet de offisielle versjonene av kulturhistoria. Arkeologer og fagmiljøer har med andre ord, vært avsendere mens lokalt situerte lekfolk (gjerne omtalt som lokalbefolkning) har vært mottakere. Formidlingen har fram til 1990tallet i hovedsak funnet sted gjennom populærvitenskapelige tidskrifter, lokalhistoriske årbøker og utstillinger. Professor Povl Simonsen (1922-2003) ved Tromsø Museum kan sies å være en av få arkeologer i sin tid som også hadde et stort fokus på muntlig formidling. Han var opptatt av at forskningsresultatene skulle formidles muntlig i møte med lokalbefolkning (Olsen 2004). Simonsen ledet en rekke arkeologiske utgravninger i Tromsø $\mathrm{Mu}$ seums distrikt fra 1950-tallet av og til midten av 1980-tallet. Simonsens formidling hadde få andre paralleller i sin samtid i Nord-Norge siden de færreste arkeologiske forskningsprosjekter eller undersøkelser vektla formidling som en integrert del av prosjektgjennomføringen. I Finnmark fylke ble det i løpet av 1970- og 1980-tallet gjennomført flere større arkeologiske utgravingsprosjekter i forbindelse med vegog vannkraftutbygging blant annet i kommu- 
ELIN Rose Myrvoll

nene Alta, Porsanger, Måsøy og Gamvik. Muntlig formidling gjennom egne arrangementer ble generelt lite vektlagt i disse prosjektene. I Iversfjord i Gamvik kommune, ble de arkeologiske funnene vist fram under et arrangement på den lokale skolen. Selv om det ble publisert utgravingsrapporter og populærvitenskapelige artikler som formidlet forskningsresultater fra disse prosjektene, må en likevel kunne anta at åpne arrangementer og muntlig formidling ville nådd flere i de enkelte lokalsamfunnene.

I løpet av 1990-tallet fikk man imidlertid et økende fokus på at formidlingen av arkeologiske prosjekter også skulle skje lokalt, og bestå av direkte kontakt mellom de tilreisende arkeologene og lokalsamfunnet. Som et eksempel på dette, nevnes Statoils planlagte ilandføringsanlegget for gass på Slettnes i Hammerfest kommune. Ett av vilkårene for frigivningen av kulturminnene var at Statoil som utbygger, skulle finansiere en vandreutstilling. Utstillingen skulle også vises lokalt og formidle resultater fra utgravningene. I tillegg ble det i løpet av prosjektperioden (1991-1993) arrangert åpne dager hvor innbyggerne i kommunen ble invitert til utgravingsfeltene. Planene for ilandføringsanlegget ble i ettertid endret, og Melkøya ble i stedet lansert som lokalitet for anlegget. Også denne lokaliseringen medførte konflikt med kulturminner i Hammerfest kommune. På nytt ble det i vilkårene for frigivning forutsatt at Statoil skulle finansiere ei utstilling, men denne gangen var utstillinga ikke rettet mot lokalsamfunnet. Den ble i stedet bygd opp som en del av de faste utstillingene til Tromsø Museum-Universitetsmuseet som ligger 450 kilometer sør for den utgravde lokaliteten på Melkøya. Utstillinga ble åpnet i 2006 og fikk navnet Ilden i sentrum.

På slutten av 1800-tallet og første halvdel av 1900-tallet var de fleste arkeologiske utgravinger basert på lokal arbeidskraft. Dette var vanlig i de fleste av de norske landsdelsmuseenes distrikter. I Nord-Norge benyttet Povl Simonsen på 1950- og 60-tallet dessuten innleide arkeologistudenter og fagfolk fra universiteter i Norge, Sverige, Danmark, Finland England og Frankrike (Simonsen 1961:9-10, 1963: 7). Etter at undervisningsenheten for arkeologi ble opprettet ved Universitetet i Tromsø på slutten av 1970-tallet, ble det lokale innslaget på arkeologiske utgravinger sjeldnere. Det var ikke lenger behov for lokal hjelp og arbeidskraft. På 1990-tallet ble det på ny vanligere at lokalbefolkningen deltok i utgravningsarbeid. Ikke av praktiske årsaker, men fordi en i tillegg til muntlig formidling, ønsket å involvere lokalbefolkningen i selve utgravningsarbeidet.

Det økte fokuset på formidling og lokal involvering i arkeologiske forskningsprosjekter i løpet av 1990-tallet har blitt videreført etter årtusenskiftet. Fokuset på formidling kan blant annet sees i sammenheng med kravene Norges forskningsråd har stilt til sine søkere om at alle søknader, skal inneholde en formidlingsplan: Forskningsrådet legger stor vekt på at resultater fra prosjekter finansiert av Forskningsrädet skal formidles på en god og effektiv måte, både vitenskapelig $i$ anerkjente journaler og tidsskrifter og popularvitenskapelig i forhold til brukergruppene (http://www.forskningsradet.no).

En liknende utvikling kan sees i Sverige. Den statlige utredningen Uppdragsarkeologi i tiden (2005) har pekt på at formidling til allmennheten bør inngå i virksomheten til oppdragsarkeologien. For å synliggjøre problemstillinger knyttet til arkeologiens møte med publikum, satte Statens historiske museum i Stockholm i gang et utviklingsprosjekt Publik arkeologi. Boka Publik arkeologi (2007) av Fredrik Svanberg og Katty H. Wahlgren er kom- 
met ut som ett av resultatene i dette prosjektet. Svanberg og Wahlgren diskuterer i Publik arkeologi hvordan arkeologien har vært kommunisert til lokalsamfunn og allmennhet. Inspirert av public archaeology poengterer deviktigheten av kommunikasjon og dialog, og skisserer konkrete forslag til hvordan denne tilnærmingsmåten kan integreres $\mathrm{i}$ arkeologiske prosjekter. De foreslår blant annet at kognitiv kartering skal inngå som en del av planleggingsfasen i arkeologiprosjekter. Kognitiv kartering innebærer at lokalbefolkning får mulighet til å beskrive hvordan de forstår et landskap og hvilke kvaliteter og historier de knytter til det (Svanberg og Wahlgren 2007: 71-73, 135). Formålet med den kognitive karteringen eller kartleggingen er å dokumentere også andre dimensjoner ved et område, enn bare de fredete kulturminnene.

\section{FORMIDLING OG ASYMMETRI}

Hvilke etiske implikasjoner er forbundet med arkeologens rolle som formidler på en lokal arena? Formidling av kulturhistorie vil alltid innebære elementer av asymmetri. Asymmetrien vil være situert i selve formidlingssituasjonen som forutsetter at den ene parten har rollen som formidler/avsender, og den annen har rollen som mottaker. Før formidling kan finne sted, må mottakeren akseptere denne rollefordelingen. Autoritet som kvalifisert forvalter og produsent av historier om fortida, oppnår formidleren/arkeologen blant annet gjennom sin tilknytting til et profesjonalisert fagmiljø. Videre konstitueres og understrekes arkeologens autoritet som ekspert, gjennom bruk av avansert utstyr og vitenskapelige feltmetoder som fotografering, innmåling, kartlegging, analyser av jord, bein, trekol og pollen etc. Arkeologenes gjøremål og opptreden i feltsituasjoner tydeliggjør at deres kunnskap er generert på et annet vis enn den lokale kunnskapen. Arkeologene kan dessuten øse av et rikholdig repertoar som inneholder ingredienser som svimlende tidsdybder, beretninger om edle metaller, fattigdom og slaveri, konger og sosial elite, konflikter, innovasjoner, reiser over store avstander etc. De har derfor en unik mulighet til å formidle historier som ikke bare har autoritet, men som også fenger, forbløffer og overrasker mottaker/tilhører. Gjennom sin tilgang til arkeologiske materiale og vitenskapelige metoder kan de formidle historier som overgår lokalt produserte historier. Arkeologene har ved hjelp av disse sterke historiene en mulighet til å påvirke de lokale oppfatningene om kulturminner. I tillegg vil det lokalt finnes egne forventninger til arkeologenes rolle som historieforvaltere og formidlere. Tv-programmer om arkeologi på kanaler som Discovery og National Geographic, er med på å forme befolkningens oppfatninger om denne yrkesgruppa. I slike programmer framstilles gjerne komplekse problemstillinger som endimensjonale mysterier eller gåter. Seerne får være flue på veggen og følge arkeologenes nitide arbeid (og bruk av avanserte instrumenter og teknologi) mot den endelige løsningen på de ulike gåtene. Disse programmene påvirker befolkningens forventninger både til hvordan de tror arkeologene arbeider og til hvordan historiene om fortida skal presenteres.

\section{ARKEOLOGEN SOM FORMIDLER}

Lise Brekmoe har i sin studie Fortellinger om fortiden: en analyse av kulturminneoppfatninger i marginale kystsamfunn i Nordland (2004) tatt utgangspunkt i tre lokalsamfunn i Nordland fylke: Fleinvær i Gildeskål kommune, Ness i Hamarøy kommune og Bliksvær i Bodø kom- 
82 mune. Hennes analyse tok utgangspunkt i en spørreundersøkelse samt 19 dybdeintervjuer på de nevnte stedene. Det kom fram at arkeologene som hadde foretatt utgravinger eller besøk på de nevnte stedene, og som muntlig hadde formidlet kunnskap om kulturminnene, ble husket lengst lokalt (2004: 47-48). De arkeologiske utgravingene som fant sted på slutten av 1800-tallet i Ness, var fremdeles kjent av $15(50 \%)$ respondenter fra dette stedet. Utgravningene i 1982, ble derimot ikke husket av mer enn to respondenter fra Ness. Brekmoe knytter denne forskjellen til hvordan arkeologene har opptrådt ovenfor lokalbefolkningen. Hun hevder at arkeologer som har tatt seg tid til samtaler og formidling, huskes og setter spor etter seg i lokalsamfunnene (2004: 4647).

Det nevnte eksempelet viser at arkeologenes historier kan ha stor gjennomslagskraft lokalt, når de formidles av personer som har evne og vilje til å fange tilhørernes oppmerksomhet. Dette innebærer ikke nødvendigvis at alle i et lokalsamfunn vil akseptere en hver fortelling om fortida som arkeologene formidler. En medvirkende årsak til at historiene har fått gjennomslagskraft og huskes, kan være at arkeologene har presentert ei fortid som lokalbefolkningen fant akseptabel, behagelig og endog smigrende. Arkeologenes historier vil kunne bli avvist hvis de divergerer for mye fra det som lokalt oppfattes som ei behagelig fortid (jf Krogh 1999). I et område hvor de fleste hovedsaklig identifiserer seg med en norsk majoritetskultur, vil arkeologenes tolkninger av lokale kulturminner i favør av en minoritet eller den samiske urbefolkningen, kunne møte motstand. Det kan også finnes sterke lokale meningsprodusenter som aktivt opponerer mot arkeologenes fortellinger. De kan i stedet målbære konkurrerende fortellinger og hente sin argumentasjon fra pseudovitenskapelige diskurser jamfør diskusjoner rundt Thor Heyerdahls teorier eller forenklete utsagn om fler-etninske landskap (Adriansen 2002).

\section{KULTURMINNER OG LOKALE KUNNSKAPSHIE- RARKIER}

Brekmoe har vist at stedene Ness, Bliksvær og Fleinvær har enkeltpersoner og grupper som er særlig aktive i formidlingen av stedenes historie. Disse ressurspersonene er: dels oppnevnt av lokalsamfunnet gjennom anerkjennelse av vedkommendes kunnskap, dels oppnevnt av dem selv gjennom aktivitet i forbindelse med innsamling av kunnskap (Brekmoe 2004:59). Et annet interessant trekk var at andre informanter som lokalt, ikke hadde status som fortellere og forvalter av stedets historie, vegret seg for å bidra i den lokale diskursen (Brekmoe 2004:59). Brekmoe påpeker også at ressurspersonene gjerne fortalte ensidige historier der fokuset særlig var rettet mot vikingtid og fordums storhetstid. Arkeologene bør, i følge Brekmoe, ha interesse av et godt forhold til slike ressurspersoner fordi disse personene i praksis er arkeologenes stedfortredere lokalt (Brekmoe 2004: 61).

Jeg ser det som et interessant funn hos Brekmoe, at historiene som ble formidlet av lokale innbyggere og i lokale sammenhenger, inngikk i et hierarki der noen historier og formidlere hadde større autoritet enn andre. Hun diskuterer imidlertid ikke de etiske sidene ved å styrke ressurspersonenes rolle i lokalsamfunnet. I den grad arkeologenes formidling har gjennomslagskraft lokalt, vil det ikke være uten betydning hvem arkeologenes formidling rettes til. Hvis formidling fra arkeologer og fagmiljøer primært rettes til og fanges opp av lokale ressurspersoner, vil deres posisjon som historieforvaltere i lokalmiljøet kunne styrkes 
ytterligere. De lokale ressurspersonenes historier om fortida vil også trolig bli mer lik arkeologenes og fagmiljøenes historier. Kontrasten mellom ressurspersonenes historier og de øvrige historiene i lokalsamfunnet, vil bli mer markant. Kunnskapen og historiene til personer uten denne statusen, vil trolig devalueres ytterligere og eventuelt forstumme. I et slikt perspektiv er det ikke likegyldig hvilke kulturminner og kulturminnetyper arkeologene viser interesse for (jf Krogh 1999; Pramli 1999).

Arkeologisk feltarbeid har hovedsakelig vært konsentrert om automatisk fredete kulturminner. Formidlingen fra arkeologenes side har følgelig vært konsentrert om kulturminner med denne fredningsstatusen. Innenfor gruppa automatisk fredete kulturminner har dessuten enkelte perioder, og kulturminnetyper fătt større fokus enn andre. Nasjonsbygging, administrative, økonomiske og politiske strukturer har vært med på å forme meningsinnholdet i begrep som majoritet-minoritet, sentrum-periferi. Det har likeledes hatt innvirkning på hvilke kulturminner og kulturminnetyper som har vært i fokus i arkeologien samt hvordan de har blitt tolket og presentert (bl.a. Schanche og Olsen 1985; Amundsen et al. 2003, Loeffer 2005). David Loeffler har i sin studie av Norrlands arkeologi sagt følgende: ... archaeologists unless acutely aware of the historical context in which they themselves move and work, risk legitimising debilitating economic and political power relationships in the present through their study and presentation of the past (Loeffler 2005:vi). Anders Gustafsson og Håkan Karlsson (2004) har analysert brosjyrer, skilttekster og reisehandbøker som presenterer tilrettelagte kulturminner. Av 27 tekster (skrevet av arkeologer og kulturminnemyndigheter) om kulturminner i Bohuslän fant de at gravfelt fra jernalderen var desidert hyppigst omtalt (39\%) (Gustafsson og Karlsson 2004: 74-78). Overrepresentasjonen skyldtes imidlertid ikke fravær av andre kulturminner: Det går inte helt att undvika tanken att Mälarlandskapet-och dess stora antal järnåldersgravfält - har fungerat som en omedveten (eller kanske medveten) mall när man valt ut lämningar för beskrivning (Gustafsson og Karlsson 2004: 78).

Kunnskapen om de eldste periodene har vært arkeologenes domene. Generelt kan en si at lokalt produserte historier i overveiende grad omhandler steder knyttet til historiske personer, hendelser og/eller landskapsbruk i nyere tid. Dette er en kunnskap som bare i liten grad har vært etterspurt av arkeologene. Det som måtte finnes av lokale historier og kunnskap om automatisk fredete kulturminner fra tida før 1500-tallet, har gjerne blitt avvist som myter uten relevans for arkeologenes virksomhet. Et unntak er lokalbefolkningens opplysninger om gjenstandsfunn og synlige strukturer på markoverflata.

Som vi har sett av Brekmoes (2004) studie, har arkeologenes formidling på lokale arenaer stor gjennomslagskraft. Arkeologenes forskning og formidling med utgangspunkt $i$ automatisk fredete kulturminner fra eldre perioder, vil kunne føre til at de lokalt tilskrives en høyere verdi enn kulturminner fra nyere tid. Statusen til disse kulturminnene understrekes ytterligere av at de gjennom loven er beskyttet mot inngrep og ødeleggelse. Bevaringen av nyere tids kulturminner derimot, er hovedsakelig et lokalt (kommunalt) anliggende. Nyere tids kulturminner kan forfalle, ødelegges eller fjernes uten at regionale kulturminnemyndigheter involveres. Fagmiljøenes ensrettete fokus på automatisk fredete kulturminner kan føre til en lignende ensretting lokalt. Det store spekteret av kulturminner og historier som er knyttet til landskapsbruk det være seg i for- 
84 bindelse med utøvelse av tradisjonelle næringer, historier om andre verdenskrig, sagn, bygninger og boplasser, hendelser, møteplasser, ferdselsveger og annet kan komme til å framstå som uviktige og uten verdi. Arkeologenes formidling av autoriserte historier om automatisk fredete kulturminner kan derfor indirekte komme til å overskygge og devaluere den lokale kunnskapen.

\section{FORBLøFFELSESPARADIGMET}

Brit Solli har i flere artikler diskutert implikasjonene som ligger i arkeologenes og kulturminnemyndighetenes fokus på å generere band, en felles identitet, mellom nåtidas og fortidas mennesker (Solli 1996;1997a; 1997b; 2003). En følge av dette identitetsparadigmet er at historiene om fortida har blitt brukt til å skape og styrke nasjonale og/eller etniske identiteter. Solli påpeker at et slikt paradigme skjerper motsetningene mellom ulike kulturer og etniske grupper. Som et alternativ til identitetsparadigmet, introduserer hun et annerledeshet- og forbloffelsesparadigme. I stedet for å knytte band mellom fortidas og nåtidas mennesker, foreslår hun at en heller kan fokusere på åpenbare forskjeller: Der ute $i$ landskapet ligger en eksotisk og forbloffende annerledes verden i form av materiell kultur som vi kan ta på à oppleve $i$ dag! Det er derfor den er så interessant, ikke fordi den ligner vair opplevelse av verden og har noe med dannelsen av vair egen kulturelle identitet (Solli 2003: 38). I tråd med dette hevder hun: Nar historien ikke lenger handler om "vaire" forfedre, men om mennesker som utgjorde fremmede kulturer, blir det uinteressant a bruke fortiden som argument $i$ nasjonalistiske sammenhenger (Solli 1997a: 177).

Det er flere implikasjoner ved Sollis forbløffelsesparadigme - blant annet i forhold til ur- folksgrupper og minoriteter som har vært fratatt muligheten til å skape sine egne faghistorier om fortida. For å bøte på dette dilemmaet foreslår Solli at det likevel må være legitimt å styrke undertrykte gruppers identitet gjennom å ty til fortida, men at majoritetsgruppenes bruk av historia til å legitimere territorielle krav, er misbruk av historia (2003:39). Dilemmaet eller innvendingen mot forbløffelsesparadigmet som Solli selv har påvist, er etter min vurdering så problematisk at det i seg selv et uttrykk for at forbløffelsesparadigmet har begrenset anvendelighet. Et annet forhold som Solli ikke diskuterer, er at bruddet mellom den forbløffende fortida og nåtida ikke trenger å være like entydig og absolutt for alle. Enkeltpersoner både innenfor såkalte majoritetskulturer og ulike urfolksgrupper kan ha kunnskap som er av betydning for forståelsen og tolkningen av kulturminner og landskapsbruk. En lokalkjent fisker vil kunne ha en annen forståelse for båtstøer og nausttufter i sitt nærområde, enn en person som kommer utenfra og som ikke har den samme lokale kjennskap og yrkestilhørighet. Heller ikke kulturminnene etter reinfangst og reindriftsutøvelse vil være like forbløffende for alle. Selv om kulturminnene kan være mange hundre år gamle, vil de kunne være gjenkjennelige og forståelige for samiske reindriftsutøvere. I tillegg til egne erfaringer har de fleste reindriftsutøvere også fått overlevert kunnskap om landskapsbruk og næringsutøvelse fra tidligere generasjoner. En person uten denne erfaringsbakgrunnen, vil i stedet kunne forbløffes over det fremmedartete som kulturminnene representere. Graden av forbløffelse henger derfor nøye sammen med kunnskap; hvem som opplever og hvilke erfaringer og kulturell kompetanse vedkommende har.

En kan også diskutere Sollis foreslåtte effekt 
av forbløffelsesparadigmet. En forbløffende annerledes fortid kan vel så gjerne være egnet til å skape identifikasjon, som det motsatte. Ta for eksempel historiene om vikingtida med ingrediensene som høvdinger, fantastiske sjøreiser, gullfunn og prestisjevarer. Slike storslåtte historier framstår som eksotiske og forbløffende når de fortelles i en lokal kystkontekst - for eksempel et mindre norsk kystsamfunn som trues av fraflytting, arbeidsledighet og marginalisering. Historiene er nettopp derfor egnet til å skape identifikasjon, og særlig hvis sporene etter vikingene fremdeles finnes i nærområdet og blir fysiske manifestasjoner på stedets fordums storhetstid. En parallell til dette kan man se innen slektsgranskning. Enkelte slektsgranskere fokuserer heller på (og identifiserer seg med) forfedre av utenlandsk og adelig opprinnelse framfor vanlige fattigfolk og allmue.

Jeg har over vært inne på at arkeologer har mange virkemidler i sitt repertoar til å skape sterke historier. Formidling i tråd med et forbløffelsesparadigme vil kunne gi disse historiene enda større kraft. De vil derfor i enda sterkere grad kunne komme til å overskygge andre historier som er mindre fargerike og autoritative. Bruddet mellom fortid og nåtid som ligger implisitt i forbløffelsesparadigmet, tar heller ikke høyde for at lokal kunnskap om kulturminner kan være en viktig og relevant ressurs for fagmiljøene.

\section{LANDSKAPET SOM ARENA FOR ULIKE ERFA- RINGER OG FORSTÅELSER}

I Norge er som nevnt, alle samiske kulturminner eldre enn 100 år automatisk fredet. Denne fredningsbestemmelsen ble innført i 1978 og lokal kunnskap om kulturminner og landskapsbruk har vist seg å være av stor verdi for fagmiljøene både i kunnskapsproduksjon om, og i forvaltning av samiske kulturminner. Det kunnskap har spilt en viktig rolle i forbindelse med registrering av automatisk fredete samiske kulturminner (Havas og Gutsol 2000; Sommerseth 2001; Svestad 2004; Myrvoll 2005 b; Barlindhaug et al. 2007). Gjennom å ta utgangspunkt i lokal kunnskap om landskapsbruk og utøvelse av primærnæringer har man funnet områder som har hatt et stort potensial for funn av kulturminner. Denne tilnærming har også bidratt til å kaste lys over sammenhengen mellom ulike kulturminner og kulturminnenes plassering i landskapet.

Lokal kunnskap har i liten grad blitt sett som relevant for de øvrige automatisk fredete kulturminnene (kulturminner eldre enn 1537) i Norge, og intervju av lokalbefolkning har sjeldent inngått i feltmetodikken. Disse kulturminnene er eldre enn 500 år, og arkeologene har trolig av den grunn, ikke sett dem som relatert til eksisterende lokal kunnskap.

Fra midten av 1990-tallet har en innenfor arkeologien, blant annet inspirert av fenomenologisk teori, sett en dreining i retning av å undersøke hvordan materiell kultur og landskap innvirker på menneskers liv og erfaringer (Olsen 2003: 91). Dette, at den fysiske verden selv innvirker og preger vår oppfattelse av den, har imidlertid ikke vært en entydig tendens. En finner også samtidige eksempler på at arkeologer har sett landskapsforståelse som et resultat av kognitive prosesser som finner sted i mennesket og uavhengig av landskapet. Ashmore og Knapp skriver i intoduksjonen til boka Archaeologies of landscapes: today, however, the most prominent notions of landscape emphasize its socio-symbolic dimensions: landscape is an entity that exists by virtue of its being perceived, experienced, and contextualized by people (Ashmore og Knapp 1999:1). 
Elin Rose Myrvoll

Stedsfilosofen Anniken Greve har i artikkelen Har stedet en natur? redegjort for det hun kaller menneskets stedssøk uten å se mennesket som verken determinert av omgivelsene eller som frakoplet eller selvstendiggjort i forhold til dem (Greve 1999: 77). Hun hevder at hvor på jorden et sted ligger, er en dimensjon ved det aktuelle stedet. De grunnleggende trekkene ved landskapsformasjonene, klimatiske forhold og vesentlige sider ved næringsgrunnlaget er naturlige forutsetninger for stedet og setter grenser for hvilket sted dette kan være. Naturen kommer her til syne som den motstanden den yter mot menneskets ønske om å skape sin egen verden (Greve 1999: 66). Marianne Skandfer har med utgangspunkt i Greves stedsfilosofi foreslått at kulturminner er rester etter tidligere tiders forstålse av bruken av landskapet (Skandfer 2003: 58). Med andre ord: boplassenes plassering i landskapet, rester av bygningskonstruksjoner, og spor etter annen ressursutnyttelse og råstoffer er utrykk for hvordan de fortidige menneskene har forstått å bruke sine omgivelser og steder. De menneskene som på et sted, har forsøkt å skape seg en verden på bakgrunn av ressursutnyttelse som fiske, jordbruk, reindrift har med andre ord måttet forholde seg til stedets naturlige forutsetninger og den motstanden som naturen har ytt.

Menneskene har opp gjennom tidene forholdt seg til de naturlige forutsetningene på ulik vis. De har benyttet seg av ulike teknologier og ulike økonomiske og sosiale strategier. Selv om de naturlige forutsetningene for stedet er ikke uforanderlige, kan de likevel knyttes til lange tidslinjer. Kunnskap om hvor det er høvelig å legge til med båt, hvor det er gode fiskegrunner, hvor det er ly for nordavinden, hvor det legger seg mye snø om vinteren eller blir tidlig snøfritt om våren, gode beiteforhold og lakseplasser, er en kunnskap som er generert ved at mennesker har måttet forholde seg til stedenes naturlige forutsetninger.

Mennesker som har tilegnet seg kunnskap om disse forutsetningene enten gjennom egen næringsutøvelse og/eller gjennom fortellinger fra tidligere generasjoner, vil kunne bidra til kunnskapsproduksjonen om kulturminner som representerer beslektet næringsvirksomheter. Dette selv om kulturminnene representerer tidsperioder som vanligvis forstås som utenfor manns minne. På denne bakgrunn skulle det være relevant for arkeologene å søke kunnskap om lokal topografi, lokal næringsutøvelse og de betingelser denne næringsutøvelsen har skjedd under. Denne kunnskapen kan supplere og utfylle kunnskapen som arkeologer ellers tilegner seg gjennom kulturminneregistreringer, arkeologiske utgravinger og kildestudier.

Lokal og landskapsrelatert erfaring og kunnskap kan være en av flere innfallsvinkler som kan bidra til å skape mangetydige og sammensatte historier om kulturminner og steder.

\section{LANDSKAP MED FÅ HISTORIER}

Jeg har over påpekt at fagfolks formidling av historier om fortida kan innebære at lokale historier forstummer, falsifiseres eller framstår som irrelevante. Det er imidlertid ikke sagt at alle steder og områder er like spekket med lokale historier (Myrvoll 2005a). Langs Finnmarkskysten ble det allerede på 1200-tallet etablert fiskevær innrettet mot kommersielt fiske. Bosetningen fluktuerte i takt med konjunksjonene i fiskeriene, og mange av dagens fiskevær har i perioder vært fraflyttet for så å bli bosatt igjen (Krogh 1999; Bertelsen et.al. 2001). Få innbyggere i fiskeværene og tettstedene på ytterkysten kan vise til slektsband 
som går flere generasjoner tilbake i tid på stedet. Dette har skapt gjentatte brudd i overleveringen av muntlige fortellertradisjoner som omhandler landskapsbruk, menneskeskapte spor i terrenget, sagn knyttet til naturformasjoner, samiske helligesteder med mere. Fornorskingstiltakene som ble rettet mot den samiske og kvenske befolkningen, har også bidratt til å underminere kunnskap om disse stedenes historie. I forbindelse med forskningsprosjektet Vernet av faste kulturminner i skjaringen mellom tradisjon og modernitet: Kulturlandskap - religion - etnisitet - nasjon og eksperter ble det gjennomført en spørreundersøkelse i Berlevåg kommune i Finnmark fylke for å kartlegge holdninger til kulturminner og kulturminnevern. Undersøkelsen som ble utført av Mia Krogh, viste at befolkningen hadde liten kjennskap til eldre kulturminner i sine nærområder (Krogh 1999). Krogh ser denne mangelen på tradisjonsmateriale som ei tilpassing til ei nåtid som ikke ser seg tjent med erkjennelsen av ei etnisk forskjellig fortid. Den sjøsamiske økonomien fra middelalderen til tidlig 1900-tall var kjennetegnet av jordbruk og variert utmarksbruk i kombinasjon med fiske. Det er derfor mulig at historier som kunne knyttes til nettopp jordbruk og utmarksbruk, hadde konnotasjoner til et samisk levevis og implisitt ei etnisk forskjellig fortid. I stedet har man fokusert på den nære homogene fortida som Berlevågs havnehistorie og moderniseringen etter krigen (Krogh 1999: 97-98).

Dette innebærer at landskapet som Berlevåg er situert i, bare i begrenset grad vil kunne være en fysisk referanse for lokale historier om fortida. I stedet framstår landskapet som en tom kulisse uten tidsdybde, og landskapskvalitetene vil hovedsakelig være knyttet til dagligliv og rekreasjon.

\section{EKSEMPELET MANGEROMSPROSJEKTET}

I det følgende skal jeg presentere hvordan forskningsprosjektet Kulturmiljøer fra jernalder til eldre historisk tid i Kyst-Finnmark. En undersøkelse med utgangspunkt i fenomenet mangeromstufter (heretter kalt Mangeromsprosjektet) formidlet sine resultater og forsøkte å involvere lokalsamfunnet i Berlevåg kommune. Mangeromsprosjektet var et tverrfaglig og internasjonalt samarbeidsprosjekt ledet av professor i arkeologi Bjørnar Olsen ved Universitetet i Tromsø. Målsettingen var blant annet å forstå de prosessene som hadde skapt større sammenhengende kulturmiljøer langs kysten av Nord-Troms og Finnmark. En sentral hypotese for prosjektet var at mangeromstuftene og kompleksiteten i kulturlandskapet var et resultat av den intensiverte kontakten mellom samene og andre etniske grupper i eldre historisk tid. Prosjektet skulle også bidra til å skape et bedre grunnlag for forvaltning og vern av disse kulturmiljøene.

De arkeologiske utgravingene i regi av Mangeromsprosjektet tok til på sensommeren $2002 \mathrm{i}$ Berlevåg kommune. I forkant var Berlevåg havnemuseum og Berlevåg barne- og ungdomskole kontaktet og informert om prosjektet og de planlagte utgravingene i kommunen. Underveis i utgravningene ble de foreløpige prosjektresultater presentert for lærerkollegiet. Det var derfor ikke ei ferdig historie som ble formidlet. I stedet for ei entydig forklaring, kunne prosjektgruppa redegjøre for en intrige nærmere bestemt problemstillingene i prosjektet. Framstillingen bar preg av å være uferdig og under diskusjon. Dette var med på å skape en upretensiøs atmosfære som åpnet for gjensidig dialog og høyttenking rundt problemstillingene. I samråd med skoleledelsen ble det også utarbeidet en plan for hvordan 
88 Mangeromsprosjektet skulle knyttes til undervisningen på skolen. I etterkant av møtet deltok hele lærerkollegiet på en fellesekskursjon til aktuelle kulturmiljøer i kommunen. Ekskursjonen omfattet ikke bare de kulturminnene som var under utgraving, men et vidt spekter av kulturminnetyper fra eldre steinalder fram til nyere tid. Man la vekt på å vise hvordan de ulike kulturminnetypene var plassert i landskapet og hvordan landskapet hadde endret seg over tid.

I 2002 da den nevnte ekskursjonen fant sted, var det registrert 318 lokaliteter (fornminnefelt) med kulturminner i Berlevåg kommune. Det samlete antallet registrerte kulturminner var imidlertid langt større, siden hver lokalitet kunne inneholde flere kulturminner. Et overveiende antall av disse lokalitetene var registret langs kystlinja der man også finner dagens riksveg. Kulturminnetettheten var med andre ord størst i de områdene som fortsatt hadde mest ferdsel, nærmere bestemt langs den smale landbremmen mellom hav og fjellfot. På tross av den høye tettheten av kulturminner, kom det fram at lærerne hadde svært liten kjennskap til disse; det være seg automatisk fredete kulturminner eller andre. De uttrykte både overraskelse og undring over at nærområdet kunne inneholde så mange og varierte spor etter fortidig bosetting. Ekskursjonsdeltakerne ga ikke utrykk for noen antagonisme eller reservasjon i forhold til kulturminnene slik Krogh fikk fram i sin studie noen år tidligere (Krogh 1999). Her skal det sies at de voksne ekskursjonsdeltakernes utsagn ikke kan forstås som representative for et tverrsnitt av Berlevågs befolkning. Ekskursjonsdeltakerne tilhørte ei relativt homogen gruppe bestående av personer i yrkesaktiv alder og med tilnærmet lik utdanningsbakgrunn. Hver og en ekskursjonsdeltaker ble heller ikke spurt eksplisitt om sine holdninger til kulturminner og kulturminnevern, men sto fritt til å ytre sitt syn i samtalene som fant sted i løpet av ekskursjonen. Respondentgruppa i Kroghs studie inneholdt større variasjoner med hensyn til alder, yrkesbakgrunn og utdannelse, og respondentene ble spurt eksplisitt om holdninger (Krogh 1999). Jeg vil likevel antyde at det lokalt kan ha skjedd en holdningsendring. Kroghs studie med tilhørende kulturminneregistreringer og intervjuer kan i seg selv ha bidratt til dette. Etter tusenårsskiftet hadde dessuten politisk nivå i kommunen og kommuneadministrasjonen i større grad fokusert på kultur og kulturminner. Det var også etablert næringsvirksomhet (reiseliv) med utgangspunkt i kulturminner i kommunen.

Resultatene fra Mangeromsprosjektet ble også formidlet til lokalsamfunnet i åpne foredrag under arrangementet Sommer i Berlevåg både i 2003 og 2004. Foredragene hadde stor oppslutning lokalt. I tillegg til den direkte kontakten med lokalsamfunnet ble det publisert populærvitenskapelige artikler i kommunens lokale magasin Berlevågingen (Henriksen 2002b, 2004; Myrvoll 2003b). Prosjektet ble også presentert i det populærvitenskapelige programmet Schrödingers katt i NRK1 i 2002. Det ble også opprettet et eget nettsted for prosjektet, og feltrapporter om registreringene og utgravingene ble distribuert til lokale museer, regional kulturminneforvaltning og enkeltpersoner (Henriksen 2002a; Myrvoll 2002, 2003a; Jensen 2003; Myrvoll og Henriksen 2003).

Som nevnt over, hadde lokalbefolkningen i Berlevåg liten kjennskap til kulturminner i de delene av kommunen som Mangeromsprosjektet arbeidet i. Kontakten mellom fagfolkene i Mangeromsprosjektet og lokalbefolkningen kan, slik sett, sies å ha vært en enveis for- 
midling av viten om disse områdene fra fagfolk til lokal befolkning. Jeg vil likevel hevde at kontakten mellom fagfolk og lokalbefolkning i overveiende grad var preget av dia$\log$ og gjensidighet. Problemstillingene i prosjektet ble framstilt som sammensatte og uten entydig svar eller løsninger. Kontakten mellom prosjektpersonell og lokalsamfunnet var heller ikke utelukkende knyttet til formidlingssituasjoner. I forbindelse med gjennomføringen av feltarbeidet i Berlevåg somrene 2001-2005 oppsto det en rekke praktiske utfordringer knyttet til utstyrsbehov, losji, lagring av feltutstyr, etc. Kommuneadministrasjonens var gjennom hele prosjektperioden involvert i prosjektet og hjalp til med å finne løsninger på disse utfordringene. Gjennom oppholdene i Berlevåg fem somrer på rad ble deltakerne i prosjektet kjent med lokalbefolkningen og deltok også i det sosiale dagliglivet $\mathrm{i}$ tettstedet. Alt $\mathrm{i}$ alt førte dette til at kontakten mellom prosjektdeltakere/fagfolk og lokalbefolkning var preget av samhandling, gjensidighet og kommunikasjon.

Gjentatte brudd i overføring av stedsrelatert kunnskap om fortida vil også kunne gjelde for andre steder langs Finnmarkskysten. Det er rimelig å anta at historier om fortida i større grad er bevart i bygder som har hatt og har stabil bosetting knyttet til småskala jordbruk og fiske, reindrift eller annen landskapsrelatert næring. Man kan derfor forvente at det finnes flere historier om fortida og landskapsbruken i indre fjordstrøk og i indre strøk av Finnmark der jordbruk og/eller reindrift har hatt en mer dominerende posisjon.

Den generelle fraflyttingen fra rurale strøk de siste femti årene har ført og fører til at også områder med tidligere stabil bosetting står igjen med stadig færre forvaltere og bærere av lokale og stedsrelaterte historier og fortellinger om fortida. I og med at historiene hovedsakelig er knyttet til en muntlig fortellertradisjon og bare i liten grad er bevart skriftlig, vil de forstumme hvis de ikke holdes i hevd. Stedene tømmes med andre ord ikke bare for bosetting, men også for stedsrelaterte historier og kunnskap om fortida. Situasjonen på slike steder er derfor en helt annen enn i lokalsamfunn som fortsatt har en relativt stabil bosetning.

I områder der det finnes få overleverte historier om fortida, vil arkeologenes historier kunne være med på å tilbakeføre stedsrelatert innhold til landskapet. Fra å være, i beste fall, en vakker kulisse, vil landskapet på ny kunne knyttes til fortellinger og hendelser. Arkeologenes metoder for å tolke og forstå landskap vil også kunne være et redskap som lokalbefolkningen kan ta i bruk. Det er derfor et poeng at arkeologene i tilegg til å vise og fortelle om steder, også redegjør for og viser hvor en kan finne kulturminner i landskapet. Det vil kunne dyktiggjøre lokalbefolkning til selv å finne kulturspor og til å vurdere potensial for kulturspor. Det vil også være et redskap som kan brukes uavhengig av kulturell bakgrunn. Dette redskapet eller lesemetoden, vil både kunne brukes i nærområdene og i andre lignende landskapstyper av beslektet karakter. Metoden vil således kunne gjøre områder utenfor den lokale sfæren mer forståelige eller lesbare for folk. Metoden vil kanskje særlig være anvendbar på kysten av Finnmark fordi det der fortsatt er bevart svært mange synlige spor fra fortidige perioder både fra de siste århundrene og fra de eldste tider.

I de senere årene har de kulturhistoriske fagmiljøene i sterkere grad poengtert at kontakten mellom fagmiljøene og lokalbefolkning bør få karakter av dialog og toveiskommunikasjon i stedet for enveis formidling av fag- 
90 kunnskap fra den vitende til den ikke-vitende (Little 2002; Gustafsson og Karlsson 2004; Merriman 2004, Jameson 2004; Svanberg og Wahlgren 2007). Før en dialog kan oppstå må begge partene anerkjennes som likeverdige. Dette har vist seg vanskelig sett fra arkeologenes ståsted. Lekfolks fortellinger om automatisk fredete kulturminner har ofte divergert fra arkeologenes forståelser av de samme kulturminnene. Det er imidlertid viktig at arkeologene, har klart for seg at de lokale fortellingene, selv om de ikke er vitenskapelig begrunnet, er med på å skape et mangfold i meningsproduksjonen rundt kulturminnene (se også Svanberg og Wahlgren 2007: 119).

En diskvalifisering av de lokale historiene vil i ytterste konsekvens kunne få de til å forstumme. I lokalsamfunn der kunnskap og historier om steder står i fare for å forsvinne er det desto viktigere at arkeologene ikke utelukkende tilføre nye historier, men også bidrar til at de eksisterende lokale historiene tas vare på.

\section{EKSEMPLET MARGINALPROSJEKET}

Forskningsprosjektet The management of cultural heritage in marginalised coastal communities (heretter kalt Marginalprosjektet) er finansiert av Norges forskningsråd. Fire såkalt marginaliserte områder ble undersøkt i kommunene Lurøy, Gildeskål, Sørfold og Øksnes i Nordland fylke. Marginalprosjektet ledes av professor i arkeologi Reidar Bertelsen ved Universitetet i Tromsø, og hovedmålet for prosjektet er tredelt. De tre delene er knyttet opp til ei målsetting om: I) Å etablere ei kulturhistorie som relaterer seg til kulturlandskapene i de utvalgte studieområdene. II) $\AA$ utvikle pålitelige metoder for kartlegging av kulturminneressurser gjennom fokus på landskap samt utvikle prognoseverktøy. III) $\AA$ utforske modeller for lokal deltakelse i kulturminneforvaltning.

Jeg skal i det videre presentere hvordan lokale aktører og institusjoner har blitt involvert og integrert i gjennomføringen av Marginalprosjektet. Feltarbeidet i Marginalprosjektet innebar registreringsarbeid i områder som var dårlig kartlagt med hensyn til kulturminner, og Norges nasjonale kulturminnedatabase $A s$ keladden inneholdt følgelig få opplysninger om områdene.

For hvert av studieområdene ble det opprettet et team av arkeologistudenter, arkeologer fra Universitetet i Tromsø og Norsk institutt for kulturminneforskning samt fagpersonell fra lokalmuseer og høyskoler i fylket. Kulturminnemyndighetene ved Nordland Fylkeskommune deltok også i noen av teamene. Feltarbeidet besto både av registrering av kulturminner og kartlegging av landskapsbruk. Registreringen av kulturminner skjedde uavhengig av deres fredningsstatus. Samarbeidet med de lokale museene viste seg å være særlig fruktbar for prosjektet. Museumspersonalet hadde detaljert kunnskap om studieområdenes kulturhistorie, og gjennom deres nettverk fikk man kontakt med personer som kunne bidra ytterligere med opplysninger. Prosjektet kunne på dette viset gjennomføre en kognitiv kartlegging basert på lokalt tradisjonsstoff og lokal kunnskap om den historiske bruken av områdene.

Til sammen ble det foretatt 716 kartfestinger av kulturminnelokaliteter i de fire studieområdene (enkelte kartfestinger representerer flere kulturminner). Av disse lokalitetene ble 451 aldersbestemt til nyere tid eller nyere tid/ uviss tid, og de er derfor ikke automatisk fredet. Enkelte kulturminner falt dessuten utenfor arkeologiens etablerte typebetegnelser (nomenklatur). Takket være lokal kunnskap om 
landskapsbruk og tradisjonelle næringer lot det seg likevel gjøre både å typebestemme og aldersbestemme en rekke av disse kulturminnene.

I studieområdene i Gildeskål og Lurøy kommuner ble det foreksempel registrert henholdsvis 60 og 180 rugehus for ærfugl (somateria mollissima). Gjennom registreringene og opplysninger fra lokalbefolkningen fikk man dokumentert den store variasjonen i materialvalg og utforming på rugehusene. Flere av rugehusene særlig de som er laget av stein og steinheller, kan være automatisk freda. Ærfuglhus er en kulturminnetype som per i dag ikke inngår i nomenklaturen til kulturminnedatabasen $A s-$ keladden. Dette til tross for at dunsanking har vært ei svært viktig næring for kystbefolkningen. Selv om driftsformen kan ha endret seg opp gjennom tidene, er det grunn til å tro at ærfuglhusene representerer en tradisjon med stor tidsdybde. Dun nevnes så tidlig som 890 e. Kr av Ottar i hans beretning for kong Alfred av Essex ca. (Lund 1983). Selv om dunsanking som næring, er marginalisert, er det fortsatt mange i kystområdene som ennå har kunnskap om denne næringen. Den lokale kunnskapen ble med andre ord en svært viktig ressurs i registreringsarbeidet, både i forhold til aldersbestemmelse, tolkning og forståelse av kulturminnene og landskapene de inngikk i.

Kunnskapen og resultatene som genereres gjennom Marginalprosjektet, forankres på flere hold. Kulturminnemyndighetene kan bruke kunnskapen fra prosjektet i sin virksomhet; ikke bare i forvaltningen av kulturminneressursene i studieområdene, men også i andre marginaliserte kystområder. Museenes deltakelse innebærer at kunnskapen blir forankret i institusjoner som har en offisiell rolle som forvaltere og formidlere av lokal kulturhistorie. Kunnskapen blir derfor gjort allment tilgjeng- elig i lokalsamfunnene. Videre vil fokuset på kulturminner uavhengig av deres fredningsstatus kunne motvirke forestillinger om at kulturminner må være automatisk fredet for å være verdifulle. Lokal kunnskap om kulturminner ble etterspurt og integrert i prosjektet på lik linje med arkeologenes. Dette bidrar forhåpentligvis også til å styrke lokalbefolkningens autoritet som bærere og forvaltere av kunnskap om kulturminner og landskapsbruk.

\section{KONKLUSJON}

Arkeologenes formidling på lokale arenaer, har gjennomslagskraft. I kraft av sin utdannelse og tilknytning til faginstitusjoner, anerkjennes og oppfattes arkeologene som autoriserte produsenter av sanne historier om fortida. Styrkeforholdet mellom den autoriserte historiefortelleren og de lokale historieforvalterne kan derfor framstå som asymmetrisk. De senere år har man i flere arkeologiske prosjekter og forsøkt å endre på denne situasjonen ved à ta $\mathrm{i}$ bruk metoder inspirert av public archaeology. I stedet for asymmetri og enveis formidling har man vektlagt dialog og interaksjon med lokal befolkning. Dersom dialog skal finne sted, forutsetter det at arkeologene anerkjenner lokalbefolkningen som bidragsytere, kunnskapsbærere og forvaltere av historier om fortida. Gjennom å vise interesse for lokal kunnskap, kan arkeologene få tilgang til lokal landskapsforståelse, landskapsbruk og ressursbruk. Dette kan generere ny kunnskap ikke bare om kulturminner fra nyere tid men også om kulturminner fra eldre tidsperioder.

Som jeg har vist over gjennom eksempler fra prosjekter i Nord-Norge må imidlertid arkeologene være seg bevisst at deres historier i kraft av sin autoriet kan utradere svakere lokale historier. Selv om arkeologene har dialog og 
92 tovegskommunikasjon som et overordnet prinsipp for sin kontakt med lokalbefolkning, har dette likevel et etisk aspekt som arkeologene må være seg bevisst. Befolkningen i områder som har vært preget av fluktuasjoner i bosettingsmønsteret, samt avstandtaking fra samisk identitet, forvalter generelt færre historier om fortida enn lokalbefolkningen i områder med stor grad av stabilitet og kontinuitet i bosettingsmønsteret. I områder hvor det finnes et stort tilfang av historier om fortida, kan arkeologenes autoritative fortellinger føre til at lokale historier falsifiseres og forstummer. Fortellinger om leirplasser på fjellet, gode båtstøer, mormors gammetuft, sennagressmyrer, ærfuglhus, stedene der de underjordiske viste seg kan lett framstå som mindre viktige i møte med arkeologenes storslåtte fortellinger om mange tusen år gamle boplasser. I områder der historiene om fortida er fătallige og/eller fraværende vil arkeologenes historier i større grad kunne være med på å tilbakeføre innhold og steder til landskapet. I tillegg vil det være desto viktigere å få bevart og videreført de få historiene som ennå måtte finnes. Som en følge av stor mobilitet de siste femti årene og fraflytting fra mindre steder, er mange i dag omgitt av landskaper som framstår som tomme kulisser uten innhold og uten steder som knyttes til historier eller hendelser. Gjennom å gjøre landskapsrelaterte historier tilgjengelige for innbyggerne, vil de få mulighet til å fylle landskapet innhold.

Dialog innebærer også et etisk aspekt knyttet til hvem som lokalt oppfordres til å delta og hvordan kunnskapen som genereres, skal forvaltes. Etter min mening er det viktig at dialog og samarbeid ikke knyttes opp til bare noen få lokale aktører. Dialog og interaksjon må finne sted på et bredt felt og gi rom for mange røster og involvere flere enn de som allerede har en posisjon som lokale historieforvaltere. Selv om en søker å dokumentere og bevare et mangfold av historier om steder og kulturminner, vil historiene likevel ikke være like verdifulle og betydningsfulle for alle. Kulturminner som kan knyttes til reindrift, vil sannsynligvis være mer verdifulle og meningsbærende for en samisk reindriftsutøver enn for noen som ikke har denne tilknytningen til og kunnskapen om landskapet.

I ettertid kan det være en fordel om kunnskapen og historiene som genereres, kan nedfelles i og forvaltes av lokale kulturinstitusjoner. Man vil da kunne motvirke at forvaltningen og videreføringen av kunnskap i for stor grad hviler på enkeltpersoner eller enkeltfamilier. Dette er likevel noe som må vurderes ut fra kunnskapens karakter og hvem som har et eierforhold til den. I Fennoskandinavia finnes kulturminner som man fra et samisk ståsted, likevel ikke ønsker skal gjøres allment kjent, fordi kulturminnene for eksempel er forbundet med gammel tro og religion eller fordi kulturminnene eller historiene utgjør en ressurs som har vært forvaltet av bestemte familier (jf. Gaski 2000). Metoder inspirert av public archaeology impliserer derfor ikke bare at arkeologene har respekt og interesse for lokalbefolkningens kunnskap om fortida, det må også innebære respekt for hvordan lokalbefolkningen ønsker at kunnskapen skal forvaltes.

\section{LITTERATUR}

Adriansen, Karsten: "Er samene Finnmarks urbefolkning? : arkeologiens muligheter til å belyse forne folkegruppers etnisitet ". Båtsfjord:Nor produkter. 2002.

Amundsen, Colin, Jørn Henriksen, Elin Myrvoll, Bjørnar Olsen, Przemyzlav Urbanczyk:"Crossing 
borders: Multi-room houses and inter-ethnic contacts in Europe's extreme north”. Fennoscandia archaeological XX, 2003: 79-100.

Ashmore, Wendy \& Arthur Bernard Knapp:"Archaeological Landscapes: Constructed, Conceptualized, Ideational". I Ashmore, Wendy \& Arthur Bernard Knapp (red.), Archaeologies of landscape: contemprary Perspectives. Blackwell, Oxford. 1999.

Barlindhaug, Stine, Thomas Risan, \& Alma Thuestad:"Kulturhistoriske registreringer Porsangmoen - Hálkavárri skytefelt". NIKU Rapport 17, 2007.

Bertelsen, Reidar, Lars Ivar Hansen \& Bjørnar Olsen:"Mellom tradisjon og modernitet: Vern av kulturminner i Nord-Norge". I Skar, Birgitte (red.): Kulturminner og miljø. Forskning i grenseland mellom natur og kultur. Norsk institutt for kulturminneforskning. 2001: 85-108.

Brekmoe, Lise: Fortellinger om fortiden. En analyse av kulturminneoppfatninger $i$ marginale kystsamfunn $i$ Nordland. Masteroppgave i arkeologi. 82 sider. Universitetet i Tromsø. 2004.

Gaski, Lina:"Landskap og identitet". Fortidsvern. nr 2, 2000:18-20

Greve, Anniken:"Har stedet en natur?" I Thuen, Trond (red.): Landskap, region og identitet: Debatter om det nordnorske. Program for kulturstudier, Norges Forskningsråd, 1999: 61-78.

Grepstad, Ottar, Kirsti Mathilde Thorheim og Guri Dahl 200:Fotefar mot nord: en kulturhistorisk reise $i$ Nord-Norge og Namdalen. Forlaget Press, Oslo. 2003.

Gustafsson, Anders \& Håkan Karlsson:"Plats på scen”. Bohusläns Museum kulturhistoriska dokumentationer $n r$ 17. Uddevalla. 2004.

Havas, Honna \& Natalia Gutsol:Kulturminnearbeid under Den Norsk - Russiske Miljøvernkommisjonen. Rapport. intervju og registreringer 19971998. Kulturminner i Østsamiske siidaer. Sametinget. 2000.
Henriksen, Jørn Erik (a):Delrapport II. Prøvegravinger 2001. Kulturmiljøer fra jernalder og eldre historisk tid $i$ Kyst-Finnmark. En undersøkelse med utgangspunkt i fenomenet mangeromstufter. Universitetet i Tromsø. 2002.

Henriksen, Jørn (b):”Spennende tuftegravninger”. Berlevågingen. 4-2002

Henriksen, Jørn:”Mangeromstuftene - ingen entydige svar". Berlevågingen.4- 2004:26-29.

Jameson, John H. JR.: "Public archaeology in the United States”. I Merriman, Nick (red.): Public archaeology. Routledge - London 2004:21-58.

Jensen, Christin: Delrapport IV. Palaeobotanical investigations. Kulturmiljøer fra jernalder og eldre historisk tid i Kyst-Finnmark. En undersøkelse med utgangspunkt i fenomenet mangeromstufter. Universitetet i Tromsø. 2003.

Krogh, Mia Helene:”Tradisjoner, landskap og folk: om kulturminner og -vern i Berlevåg: delrapport nr. 3 fra NFR-prosjektet Vernet av faste kulturminner i skjæringen mellom tradisjon og modernitet”. Stensilserie B. nr. 57. Institutt for arkeologi. Det samfunnsvitenskapelige fakultet, Universitetet i Tromsø. 1999.

Little, Barbara B.: Public Benefits of Archaeology. Gainesville 2002.

Loeffler, David:"Contested Landscapes / Contested Heritage: history and heritage in Sweden and their archaeological implications concerning the interpretation of the Norrlandian past". Achaeology and Environment 18. Umeå Universitet. 2005.

Lund, Niels: Ottar og Wulfstan. To rejsebeskrivelser fra vikingtiden. Roskilde. 1983.

Merriman, Nick: Public Archaeology. Routledge London 2004.

Miljøverndepartemenet: Stortingsmelding nr. 16 (2004-2005) Leve med kulturminner. 2005.

Myrvoll, Elin Rose:Delrapport I. Kulturminneregistreringer 2001. Kulturmiljøer fra jernalder og eldre historisk tid i Kyst-Finnmark. En undersøkelse med 
utgangspunkt i fenomenet mangeromstufter. Universitetet i Tromsø. 2002.

Myrvoll, Elin Rose (a):Delrapport V. Arkeologiske undersøkelser av hellegrop, gammetufter, og teltringer $i$ Berlevåg kommune 2002. Kulturmiljøer fra jernalder og eldre historisk tid i Kyst-Finnmark. En undersøkelse med utgangspunkt i fenomenet mangeromstufter. Universitetet i Tromsø. 2003

Myrvoll, Elin Rose (b): "Sommerens utgravinger i Berlevåg". Berlevågingen $\mathrm{Nr}$ 43, 4-2003

Myrvoll, Elin Rose \& Jørn Erik Henriksen: Delrapport III. Kulturminneregisteringer 2002. Kulturmiljøer fra jernalder og eldre historisk tid $i$ KystFinnmark. En undersøkelse med utgangspunkt ifenomenet mangeromstufter. Universitetet i Tromsø. 2003.

Myrvoll, Elin Rose (a):"Finnmarkskysten - en vev av historier”. I Paludan-Müller, Carsten og Grethe Gundhus (red.): Kulturminner en ressurs $i$ tiden. NIKU, Oslo 2005: 33-43.

Myrvoll, Elin Rose (b):"Konsekvensutredning Sjunkan-Misten, deltema kulturhistorie".

NIKU Rapport Arealplan 12/2005.

Olsen, Bjørnar:"Material Culture after Text: Remembering Things". Norwegian Arcgaeological Review 36 (2). 2003: 87-104.

Olsen, Bjørnar:"En steinalderarkeolog ved Varangerfjorden”. Ottar. Nr. 3, 2004: 5-12.

Pramli, Marthe Cecilie:"Kulturminner i Harstad: mellom forskning, forvaltning og befolkning: delrapport nr. 4 fra NFR-prsjektet Vernet av faste kulturminner i skjæringen mellom tradisjon og modernitet”. Stensilserie B nr. 58. Institutt for arkeologi. Det samfunnsvitenskapelige fakultet, Universitetet i Tromsø. 1999.

Schanche, Audhild \& Bjørnar Olsen: "Var de alle nordmenn? En etno-politisk kritikk av norsk arkeologi”. I Ness, Jenny-Rita (red.): Arkeologi og etnisitet. AmS Varia 15. 1985: 87-99.

Simonsen, Povl: "Varanger-funnene II, Fund og udgravninger på fjordens sydkyst". Tromsø Museums skrifter. Vol. VII, Hefte II. 1961.

Simonsen, Povl: "Varanger-funnene III, Fund og udgravninger i Pasvikdalen og ved den østlige fjordstrand". Tromsø Museums skrifter. Vol. VII, Hefte III. 1963.

Skandfer, Marianne: "Etikk i møte med det fortidige". I Seip, Elisabeth (red.): Verneideologi. NIKUseminar 4. februar og 25. april 2002. OsloNIKU Tema 5. 2003: 51-60.

Solli, Brit: "Fortida er et annet sted. Om arkeologi og kulturminnevern - røtter og føtter". Norsk antropologisk tidsskrift. 1996/2: 79-90.

Solli, Brit (a): "Ting og tid, fortellinger og identitet". I Brenna, Brita \& og Karen Marie Fjeldstad (red.): Kollektive identiteter, ting og betydninger. TMV report series, nr 24. Oslo: senter for teknologi og menneskelige verdier. 1997: 163-180.

Solli, Brit (b): "Forankring fryder? ” Ottar. Nr. 3, 1997: 15-20.

Solli, Brit: "Seks verneideologiske momenter foran et nytt årtuse". I Seip, Elisabeth (red.): Verneideologi. NIKU-seminar 4. februar og 25. april 2002. Oslo NIKU Tema 5. 2003: 33-41.

Sommerseth, Ingrid: Den samiske kulturhistoria $i$ Mauken - Blåtind. Sametinget, Miljø- og kulturvernavdelinga. 2001.

Svanberg, Fredrik og Wahlgren, Katty H.: Publik arkeologi. Nordic Academic Press och Statens historiska museum 2007.

Svestad, Asgeir: Konsekvensanalyse kulturminner og kulturmiljø. Verneplan Lomsdal-Visten, Deltema kulturhistorie. NIKU Rapport arealplan 02/2004.

Uppdragsarkeologi $i$ tiden, Statens offentliga utredningar (SOU) 2005: 80.

\section{INTERNETT}

Kulturminnedatabasen Askeladden: http://askeladden.ra.no/sok/

LOV-1978-06-09 nr 50: Lov om kulturminner (kul- 
turminneloven) http://www.statkart.no (lest mai

2008)

Norges Forskningsråd:

http://www.forskningsradet.no/servlet/Satellite?c $=$ Informasjonstekst\&cid=1195592972637\&pagename=ForskningsradetNorsk $\% 2$ FHovedsidemal (lest februar 2009)

*Elin Rose Myrvoll

Researcherlarchaeologist at the Norwegian

Institute for Cultural Heritage Research,

Tromsø, Norway

Forskerlarkeolog ved Norsk institutt for kulturminneforskning, Tromsø, Norge

Adresse: NIKU, polarmiljøsenteret,

NO-9296 Tromsø

E-mail:elin.myrvoll@niku.no 